\title{
Degradation Characters of La-Mg-Ni-Based Metal Hydride Alloys: Corrosion and Pulverization Behaviors
}

\author{
Yi-Ming $\mathrm{Li}^{1} \cdot$ Yang-Huan Zhang ${ }^{1} \cdot$ Hui-Ping Ren ${ }^{1}$
}

Received: 31 July 2017 / Revised: 24 September 2017 / Published online: 29 January 2018

(C) The Chinese Society for Metals and Springer-Verlag GmbH Germany, part of Springer Nature 2018

\begin{abstract}
Degradation behaviors of three typical La-Mg-Ni alloys, $\mathrm{La}_{2} \mathrm{MgNi}_{9}, \mathrm{La}_{1.5} \mathrm{Mg}_{0.5} \mathrm{Ni}_{7}$ and $\mathrm{La}_{4} \mathrm{MgNi}_{19}$, were studied. $\mathrm{La}_{1.5}$ $\mathrm{Mg}_{0.5} \mathrm{Ni}_{7}$ with (La, $\left.\mathrm{Mg}\right)_{2} \mathrm{Ni}_{7}$ as main phase presents better discharge capacity and cycling stability. The three alloys suffer severe pulverization and corrosion after electrochemical cycles, which are considered to be the significant factor attributing to the capacity deterioration. However, the overall corrosion extent of the three cycled alloys aggravates successively, which is inconsistent with the result that $\mathrm{La}_{2} \mathrm{MgNi}_{9}$ presented poor cycling stability and also the assumption that alloy with high $\mathrm{Mg}$ content is easy to be corroded. The intrinsic anti-corrosion and anti-pulverization characteristics of the three alloys are mainly focused in this work. Immersion corrosion experiments demonstrate that the $\mathrm{Mg}$-rich phases are more easily to be corroded. The corrosion resistance of the three alloys presents an improved trend which is inversely proportional to abundance of the Mg-rich phases. However, the anti-pulverization abilities present an inverse trend, which is closely related to the mechanical property of various phase structures. $\mathrm{LaNi}_{5}$ with the highest hardness is easy to crack, but the soft $(\mathrm{La}, \mathrm{Mg}) \mathrm{Ni}_{2}$ is more resistant to crack formation and spreading. Thus, the weaker corrosion of $\mathrm{La}_{2} \mathrm{MgNi}_{9}$ after electrochemical cycling is attributed to the better intrinsic anti-pulverization capability though the anti-corrosion is poor. As $\mathrm{La}_{4} \mathrm{MgNi}_{19}$ possesses excellent corrosion resistance, enhancement of the anti-pulverization ability is urgent for improvement in the cycling stability.
\end{abstract}

Keywords La-Mg-Ni-based alloys · Degradation behaviors $\cdot$ Corrosion $\cdot$ Pulverization

\section{Introduction}

RE-Mg-Ni-based alloys have received substantial attentions over the past decades owing to their excellent electrochemical performances in the nickel/metal hydride $(\mathrm{Ni} /$ $M \mathrm{H})$ battery [1-5]. To date $A_{2} B_{7}$-type $\mathrm{RE}-\mathrm{Mg}-\mathrm{Ni}$ alloys have been applied successfully in the commercial $\mathrm{Ni} / M \mathrm{H}$ batteries [3]. However, $A B_{2}$ and $A B_{3}$-type $\mathrm{RE}-\mathrm{Mg}-\mathrm{Ni}$ alloys present poor cycling stability though the theoretical

Available online at http://link.springer.com/journal/40195

Electronic supplementary material The online version of this article (https://doi.org/10.1007/s40195-017-0696-y) contains supplementary material, which is available to authorized users.

Hui-Ping Ren

renhuiping@sina.com

1 Key Laboratory of Integrated Exploitation of Bayan Obo Multi-Metal Resources, Inner Mongolia University of Science and Technology, Baotou 014010, China discharge capacities are higher than $\mathrm{A}_{2} \mathrm{~B}_{7}$-type alloys [6-8]. In addition, $A_{5} B_{19}$-type alloys have been reported to possess good electrochemical performances, but the cycling stability still need further development to meet the practical requirements $[9,10]$.

Degradation of the discharge capacity is considered to be mainly attributed to pulverization and corrosion of the electrode alloys during the reversible electrochemical cyclings [11, 12]. Corrosion of the alloys leads to direct degradation of the discharge capability, and pulverization improves corrosion due to the fresh surface of the alloy particles continuously exposing to the electrolyte. As to the $\mathrm{RE}-\mathrm{Mg}-\mathrm{Ni}$ alloys, it is found that these alloys are easily to be corroded into $\mathrm{RE}(\mathrm{OH})_{3}$ and $\mathrm{Mg}(\mathrm{OH})_{2}$ [13-15]. And these kinds of corrosion products are loose and passive which cannot protect the matrix from further corrosion $[15,16]$. Severe pulverization of RE-Mg-Ni alloys during cycling had also been reported in numerous works [13-17]. Degradation process of La-Mg-Ni-Co alloys has been classified into three stages: the pulverization and $\mathrm{Mg}$ 
oxidation stage, the $\mathrm{Mg}$ and $\mathrm{La}$ oxidation stage and the oxidation and passivation stage [14]. Thus, further improvement in the anti-pulverization and anti-corrosion resistant of the RE-Mg-Ni-based alloys is considered to be significant for the cycling stability. In addition, degradation of the hydrogen storage alloys is also demonstrated to be affected by the structural distortion upon the hydrogenation cyclings. Our previous works demonstrated that $\mathrm{La}-\mathrm{Mg}-\mathrm{Ni}$ alloys suffered hydrogen-induced amorphization (HIA) which remarkably worsened both the gas-solid and electrochemical storage capability $[18,19]$.

There are several compounds including $A B_{2^{-}}, A B_{3^{-}}$, $A_{2} B_{7^{-}}$and $A_{5} B_{19}$-type phases existing in the RE-Mg-Ni system, which makes the phase constitution of these alloys more complex $[4,5]$. It is well accepted that $A_{2} B_{7}$-type structure has better cycling stability than other phases. Li et al. reported that $A B_{3}$ phase was easily corroded by $\mathrm{KOH}$ [20]. Liu et al. [21] prepared singles phase $\mathrm{La}-\mathrm{Mg}-\mathrm{Ni}$ alloys by stepwise powder sintering method and found that $\mathrm{La}_{3} \mathrm{MgNi}_{14}$ with $A_{2} B_{7}$-type phase presented good cycling stability, which was closely related to the pulverization trend of the alloys. Though the overall degradation characters of the RE-Mg-Ni-based alloys have been investigated in quite a number of works, diversity of the degradation characteristics of various compounds in this system is still lacking. In particular, coexisting of pulverization, corrosion and the structural distortion during the charge/discharge cycles makes it difficult to illustrate the degradation mechanisms of the individual phase.

Accordingly, understanding the distinction of degradation behaviors of the individual phase is the precondition for improvement in the cycling stability of the RE-Mg-Nibased alloys. In the present study, degradation mechanisms of three typical La-Mg-Ni alloys: $\mathrm{La}_{2} \mathrm{MgNi}_{9}, \mathrm{La}_{1.5} \mathrm{Mg}_{0.5}$ $\mathrm{Ni}_{7}$ and $\mathrm{La}_{4} \mathrm{MgNi}_{19}$ have been systematically investigated. Corrosion and pulverization behaviors of the alloys, especially the intrinsic characteristics of the $A B_{3^{-}}, A_{2} B_{7^{-}}$and $A_{5} B_{19}$-type La-Mg-Ni phases during absorption/desorption cycling were generated.

\section{Experimental}

The as-cast $\mathrm{La}_{2} \mathrm{MgNi}_{9}, \mathrm{La}_{1.5} \mathrm{Mg}_{0.5} \mathrm{Ni}_{7}$ and $\mathrm{La}_{4} \mathrm{MgNi}_{19}$ alloys were prepared using induction levitation melting in an argon atmosphere. Excessive $\mathrm{Mg}$ was added since some $\mathrm{Mg}$ would evaporate in the melting process. The alloys were melted two times and metallographic observation in large areas (about $5 \mathrm{~mm} \times 5 \mathrm{~mm}$ ) showed a uniform character indicating the microstructural homogeneity of the ingots, as displayed in Fig. S1 in the supplementary information. Then the as-cast alloys were annealed at 1143 ,
1173 and $1193 \mathrm{~K}$, respectively, for $6 \mathrm{~h}$ protected in argon atmosphere.

The compositions of the ingot were determined by inductively coupled plasma atomic emission spectrometer (ICP-AES) using a ThermoFisher iCAP-6300 system. Metallographic microstructure of the alloys was observed using a laser scanning confocal microscope (LSCM, Olympus-OLS4000) and a scanning electron microscope (SEM, FEI-Qanta 400). Chemical composition was studied by energy dispersive spectroscopy (EDS). A Bruker-D8 Advance X-ray diffractometer (XRD) was used to detect the crystal structure of the alloys. The microstructural and crystallographic information were also measured by a fieldemission transmission electron microscope (TEM, JEOL2100 and FEI-F20).

Particle size of the cycled alloys was tested under a laser particle size analyzer (Malvern-Mastersizer 3000). Oxygen content of the electrochemical cycled and immersed alloys was performed on a nitrogen/oxygen tester (NCSON3000). Before the oxygen test, the samples were immersed in deionized water for $24 \mathrm{~h}$, then washed using pure alcohol twice to remove the residual $\mathrm{KOH}$ and dried in a vacuum drying oven. Vickers hardness of various phases was tested by a FUTURE-TECH FM-300 microhardness tester under 10 and 25 gf with a keeping time for $15 \mathrm{~s}$.

The pressure-composition-temperature curves $(\mathrm{P}-\mathrm{C}-$ $T$ ) of the alloys were measured by a Suzuki-2SDWIN PCT system using the Sievert's method. Before the $P-C-$ $T$ measurement, the samples were pumped at $473 \mathrm{~K}$ for $2 \mathrm{~h}$, hydrogenated under $3 \mathrm{MPa}_{2}$ (purity 99.999\%) for $5 \mathrm{~h}$ at $303 \mathrm{~K}$, and then evacuated at $573 \mathrm{~K}$ for $2 \mathrm{~h}$. The activated samples were also hydrogenated at $2 \mathrm{MPa}$ for $600 \mathrm{~s}$ and desorbed by evacuating at $298 \mathrm{~K}$ for $1200 \mathrm{~s}$ for gaseous cycles.

The particles with dimension of about $40-50 \mu \mathrm{m}$ were used for the electrochemical test and details of preparation of the electrode pellets can be found in Ref. [18]. The electrode pellets were firstly immersed in $6 \mathrm{~mol} \mathrm{~L}^{-1} \mathrm{KOH}$ aqueous solution for $1 \mathrm{~d}$, charged at a current density of $105 \mathrm{~mA} \mathrm{~g}^{-1}$ for $4 \mathrm{~h}$, followed by a rest for $10 \mathrm{~min}$, then discharged at the same current density to the cutoff voltage of $-0.6 \mathrm{~V}$.

\section{Results and Discussion}

ICP results of the annealed $\mathrm{La}_{2} \mathrm{MgNi}_{9}, \mathrm{La}_{1.5} \mathrm{Mg}_{0.5} \mathrm{Ni}_{7}$ and $\mathrm{La}_{4} \mathrm{MgNi}_{19}$ alloys are $\mathrm{La}_{2.087} \mathrm{Mg}_{0.913} \mathrm{Ni}_{9.103}, \mathrm{La}_{1.520-}$ $\mathrm{Mg}_{0.480} \mathrm{Ni}_{7.064}$ and $\mathrm{La}_{4.076} \mathrm{Mg}_{0.924} \mathrm{Ni}_{19.038}$, respectively, which are close to that of the designed composition except a little excess of Ni which may be due to the loss of $\mathrm{La}$ and $\mathrm{Mg}$ during the melting and annealing processes. 


\subsection{Microstructure and Hydrogen Storage Performance}

Metallographic microstructures of the three alloys observed by LSCM and backscattering electronic (BSE) micrographs are shown in Fig. 1. It shows that four contrasts can be detected for the $\mathrm{La}_{2} \mathrm{MgNi}_{9}$ alloy, as marked with A-D in the LSCM image and 1-4 in the BSE image (similarly hereinafter). The chemical quantitation of various contrast from EDS analysis is listed in Table 1, from which the four phases are speculated to be $(\mathrm{La}, \mathrm{Mg}) \mathrm{Ni}_{2}$ $(\mathrm{La}, \mathrm{Mg}) \mathrm{Ni}_{3},(\mathrm{La}, \mathrm{Mg})_{2} \mathrm{Ni}_{7}$ and $\mathrm{LaNi}_{5}$. Five crystal structures including $\mathrm{CaCu}_{5}, \mathrm{MgCu}_{4} \mathrm{Sn}, \mathrm{PuNi}_{3}, \mathrm{Ce}_{2} \mathrm{Ni}_{7}$ and $\mathrm{Gd}_{2} \mathrm{Co}_{7}$ types are identified in XRD pattern of the $\mathrm{La}_{2}$ $\mathrm{MgNi}_{9}$ alloy, as shown in Fig. 2a. The structural parameters and phase contents are refined and listed in Table 2. The results are consistent with the metallographic observation that the main phase is $(\mathrm{La}, \mathrm{Mg}) \mathrm{Ni}_{3}$, then $(\mathrm{La}, \mathrm{Mg}) \mathrm{Ni}_{2}$ and $(\mathrm{La}, \mathrm{Mg})_{2} \mathrm{Ni}_{7}$, but the content of $\mathrm{LaNi}_{5}$ is rare.

In case of the $\mathrm{La}_{1.5} \mathrm{Mg}_{0.5} \mathrm{Ni}_{7}$ and $\mathrm{La}_{4} \mathrm{MgNi}_{19}$ alloy, metallographic and XRD characterization indicate that (La, $\mathrm{Mg}) \mathrm{Ni}_{2}$ disappears, $(\mathrm{La}, \mathrm{Mg})_{5} \mathrm{Ni}_{19}$ emerges and $\mathrm{LaNi}_{5}$ increases compared with $\mathrm{La}_{2} \mathrm{MgNi}_{9}$. The main phases of the $\mathrm{La}_{1.5} \mathrm{Mg}_{0.5} \mathrm{Ni}_{7}$ and $\mathrm{La}_{4} \mathrm{MgNi}_{19}$ alloys are $(\mathrm{La}, \mathrm{Mg})_{2} \mathrm{Ni}_{7}$ and $(\mathrm{La}, \mathrm{Mg})_{5} \mathrm{Ni}_{19}$, respectively, and the structural parameters and phase contents are also listed in Table 2.

Figure 3 shows the $P-C-T$ curves of the alloys, and the detailed data are given in Table 3. Theoretically, hydrogenation capability increases with reduction in the $B$-side stoichiometry in the La-Mg-Ni-based alloys. However, the maximum hydrogen absorption content of $\mathrm{La}_{2} \mathrm{MgNi}_{9}$ is slightly lower than that of $\mathrm{La}_{1.5} \mathrm{Mg}_{0.5} \mathrm{Ni}_{7}$. It is ascribed to existence of (La, $\mathrm{Mg}) \mathrm{Ni}_{2}$ phase in $\mathrm{La}_{2} \mathrm{MgNi}_{9}$ since $(\mathrm{La}, \mathrm{Mg}) \mathrm{Ni}_{2}$ can hardly absorb and desorb hydrogen at the room temperature [8]. The three alloys have analogous hydrogen absorption plateau. But both the desorption pressure and the reversible hydrogen capacity elevate with the increase in the $B$-side stoichiometry of the three alloys. Reversible hydrogen capacity of $\mathrm{La}_{2} \mathrm{MgNi}_{9}$ is only 1.15 $\mathrm{wt} \%$, and the hysteresis effect is more evident than the other alloys.

Electrochemical discharge curves of the three alloys are displayed in Fig. S2, and the detailed data are also shown in Table 3. Discharge capacities of $\mathrm{La}_{2} \mathrm{MgNi}_{9}$ and $\mathrm{La}_{4} \mathrm{MgNi}_{19}$ are lower than $\mathrm{La}_{1.5} \mathrm{Mg}_{0.5} \mathrm{Ni}_{7}$. The lower discharge capacity of $\mathrm{La}_{2} \mathrm{MgNi}_{9}$ is due to the weak reversible hydrogen storage capacity. Similar result has been reported in Ref. [22] where alloy with high content of $A B_{3}$-type phase
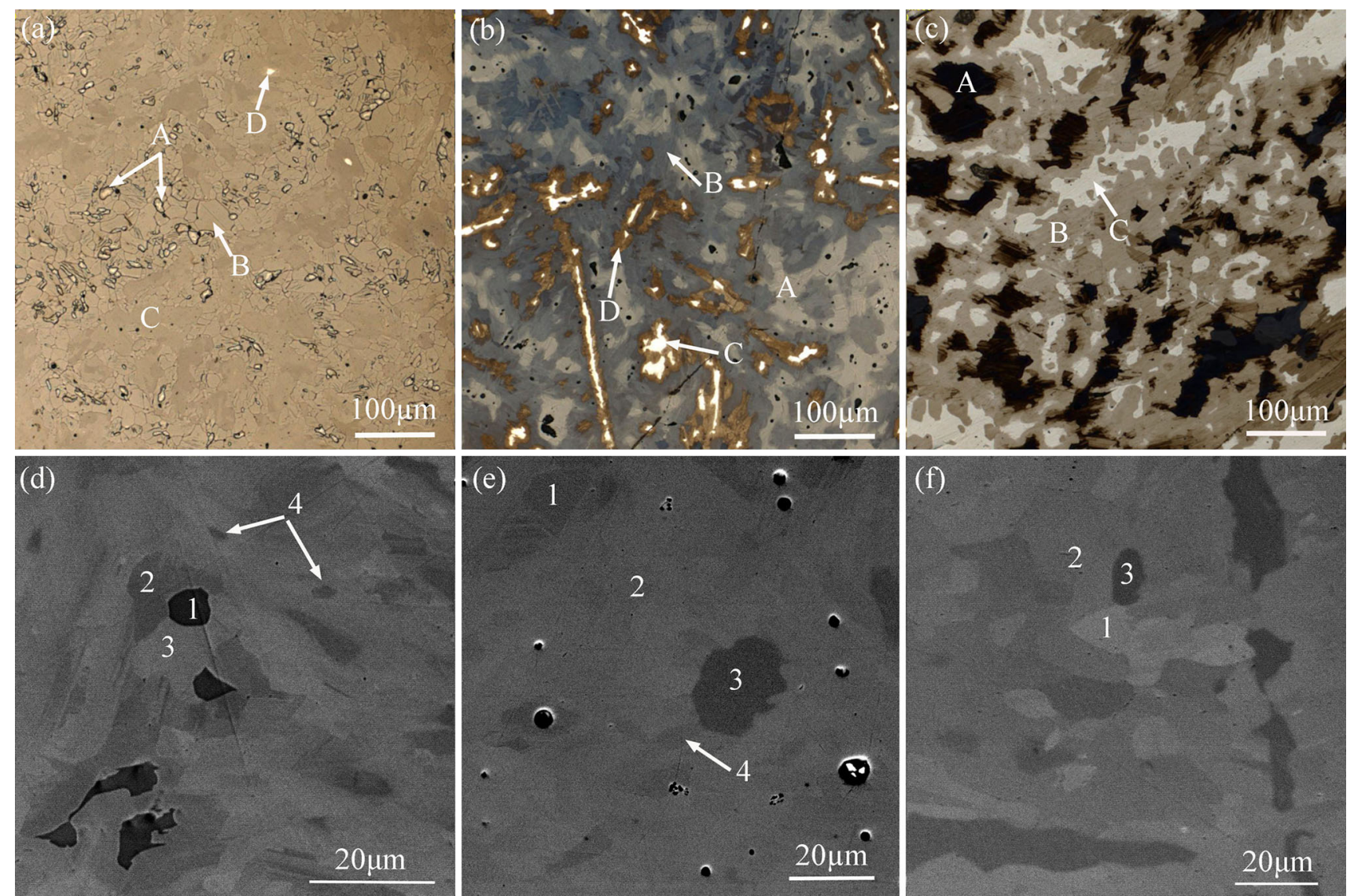

Fig. 1 Microstructures of annealed $\mathrm{La}_{2} \mathrm{MgNi}_{9} \mathbf{a}, \mathbf{d} ; \mathrm{La}_{1.5} \mathrm{Mg}_{0.5} \mathrm{Ni}_{7} \mathbf{b}, \mathbf{e} ; \mathrm{La}_{4} \mathrm{MgNi}_{19} \mathbf{c}$, f at low $\mathbf{a}-\mathbf{c}$; high d-f magnification 
Table 1 EDS results of annealed alloys corresponding to areas marked in Fig. 1

\begin{tabular}{lllllll}
\hline Alloy & Location & $\mathrm{La}$ & \multicolumn{1}{c}{$\mathrm{Mg}$} & $\mathrm{Ni}$ & $\mathrm{Ni} /(\mathrm{La}+\mathrm{Mg})$ & Phase \\
\hline $\mathrm{La}_{2} \mathrm{MgNi}_{9}$ & 1 & 16.15 & 20.69 & 63.16 & 1.71 & $(\mathrm{La}, \mathrm{Mg}) \mathrm{Ni}_{2}$ \\
& 2 & 17.93 & 9.18 & 72.89 & 2.69 & $(\mathrm{La}, \mathrm{Mg}) \mathrm{Ni}_{3}$ \\
& 3 & 19.35 & 5.16 & 76.50 & 3.26 & $(\mathrm{La}, \mathrm{Mg})_{2} \mathrm{Ni}_{7}$ \\
& 4 & 17.17 & 0.00 & 82.83 & 4.82 & $\mathrm{LaNi}_{5}$ \\
$\mathrm{La}_{1.5} \mathrm{Mg}_{0.5} \mathrm{Ni}_{7}$ & 1 & 16.31 & 10.32 & 73.01 & 2.63 & $(\mathrm{La}, \mathrm{Mg}) \mathrm{Ni}_{3}$ \\
& 2 & 18.91 & 4.51 & 76.58 & 3.27 & $(\mathrm{La}, \mathrm{Mg})_{2} \mathrm{Ni}_{7}$ \\
& 3 & 17.87 & 0.00 & 83.13 & 4.96 & $\mathrm{LaNi} 5$ \\
& 4 & 17.74 & 3.30 & 78.95 & 3.75 & $(\mathrm{La}, \mathrm{Mg})_{5} \mathrm{Ni}_{19}$ \\
$\mathrm{La}_{4} \mathrm{MgNi}_{19}$ & 1 & 18.31 & 4.37 & 77.32 & 3.41 & $(\mathrm{La}, \mathrm{Mg})_{2} \mathrm{Ni}_{7}$ \\
& 2 & 19.16 & 2.73 & 78.11 & 3.57 & $(\mathrm{La}, \mathrm{Mg})_{5} \mathrm{Ni}_{19}$ \\
& 3 & 17.35 & 0.00 & 82.65 & 4.76 & $\mathrm{LaNi}$ \\
\hline
\end{tabular}
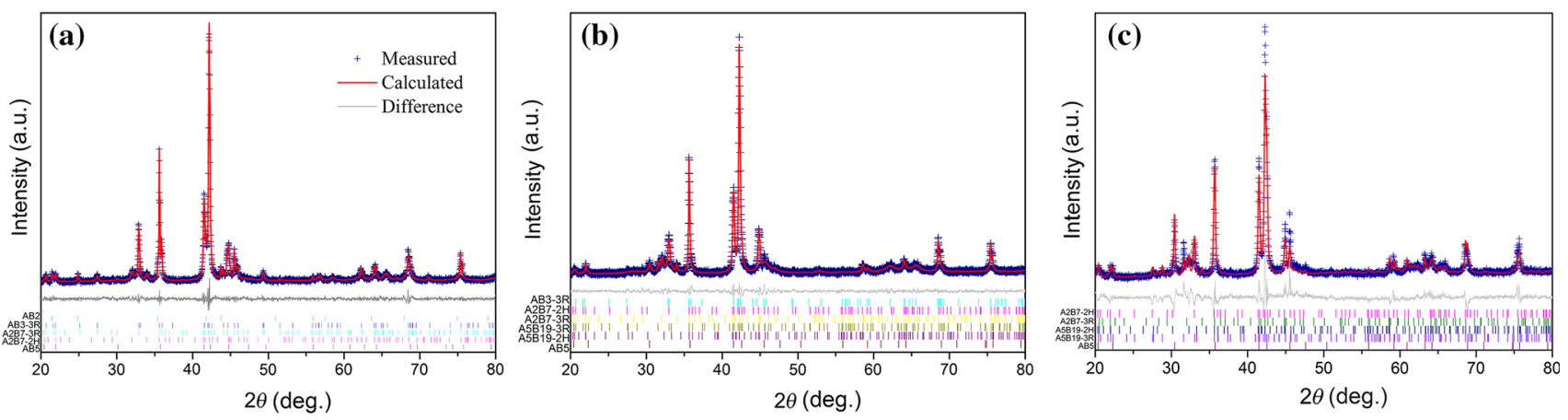

Fig. 2 XRD profiles of annealed $\mathrm{La}_{2} \mathrm{MgNi}_{9} \mathbf{a} ; \mathrm{La}_{1.5} \mathrm{Mg}_{0.5} \mathrm{Ni}_{7} \mathbf{b} ; \mathrm{La}_{4} \mathrm{MgNi}_{19}$ c

Table 2 Crystal structure, cell parameters and phase content of annealed alloys

\begin{tabular}{llllc}
\hline Alloy & $\mathrm{Phase}$ type & $a(\mathrm{~nm})$ & $c(\mathrm{~nm})$ & Content $(\mathrm{wt} \%)$ \\
\hline $\mathrm{La}_{2} \mathrm{MgNi}_{9}$ & $\mathrm{MgCu}_{4} \mathrm{Sn}$ & 0.71660 & - & 4.1 \\
& $\mathrm{PuNi}_{3}$ & 0.50358 & 2.43612 & 61.4 \\
& $\mathrm{CaCu}_{5}$ & 0.50182 & 0.39806 & 0.5 \\
& $\mathrm{Ce}_{2} \mathrm{Ni}_{7}$ & 0.50387 & 2.42605 & 13.6 \\
& $\mathrm{Gd}_{2} \mathrm{Co}_{7}$ & 0.50350 & 3.63793 & 20.4 \\
$\mathrm{La}_{1.5} \mathrm{Mg}_{0.5} \mathrm{Ni}_{7}$ & $\mathrm{PuNi}_{3}$ & 0.50339 & 2.42432 & 11.1 \\
& $\mathrm{Ce}_{2} \mathrm{Ni}_{7}$ & 0.50334 & 2.42635 & 32.6 \\
& $\mathrm{Gd}_{2} \mathrm{Co}_{7}$ & 0.50341 & 3.43493 & 21.9 \\
& $\mathrm{Ce}_{5} \mathrm{Ni}_{19}$ & 0.50319 & 4.84459 & 16.3 \\
& $\mathrm{Pr}_{5} \mathrm{Co}_{19}$ & 0.50347 & 3.22350 & 13.5 \\
& $\mathrm{CaCu}_{5}$ & 0.50182 & 0.39806 & 4.6 \\
$\mathrm{La}_{4} \mathrm{MgNi}_{19}$ & $\mathrm{Ce}_{2} \mathrm{Ni}_{7}$ & 0.50341 & 2.42416 & 22.8 \\
& $\mathrm{Gd}_{2} \mathrm{Co}_{7}$ & 0.50298 & 3.63639 & 10.7 \\
& $\mathrm{Ce}_{5} \mathrm{Ni}_{19}$ & 0.50323 & 4.83377 & 27.5 \\
& $\mathrm{Pr}_{5} \mathrm{Co}_{19}$ & 0.50328 & 3.22454 & 15.3 \\
& $\mathrm{CaCu}_{5}$ & 0.50212 & 0.39792 & 23.7 \\
\hline
\end{tabular}

presents lower gaseous and electrochemical capacity. While the high content of $\mathrm{LaNi}_{5}$ which is unsuited for the electrochemical application for the high plateau [23]

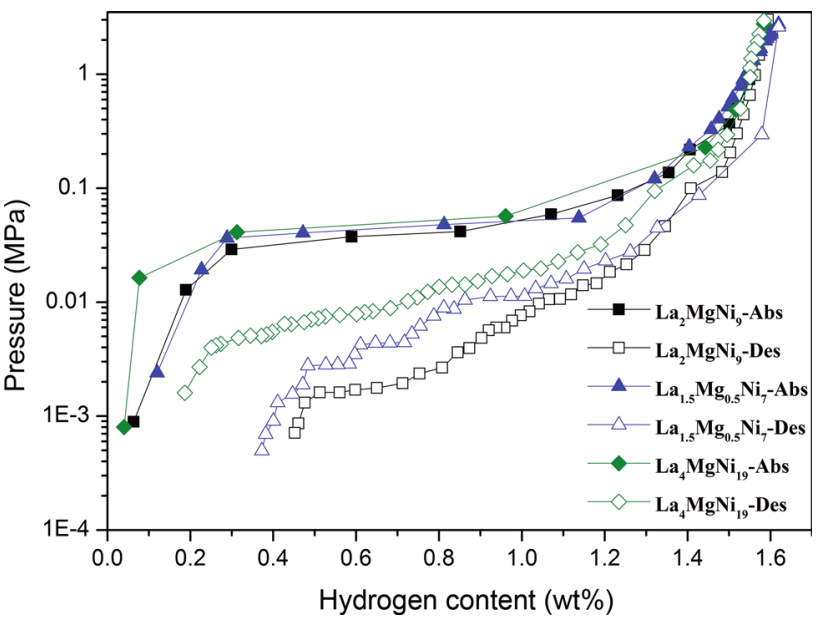

Fig. $3 P-C-T$ curves of three alloys (Abs and Des are the abbreviation for the absorption and desorption, respectively)

attributes to the lower discharge capability of $\mathrm{La}_{4} \mathrm{MgNi}_{19}$. After 100 electrochemical cyclings, capacity retention of $\mathrm{La}_{2} \mathrm{MgNi}_{9}$ is about $70 \%$, which agrees well with that of the alloy with the same composition reported by $\mathrm{Hu}$ et al. [24]. $\mathrm{La}_{4} \mathrm{MgNi}_{19}$ has similar cycling stability compared with $\mathrm{La}_{2} \mathrm{MgNi}_{9}$, while $\mathrm{La}_{1.5} \mathrm{Mg}_{0.5} \mathrm{Ni}_{7}$ presents higher capacity retention of $75 \%$. 
Table 3 Hydrogen storage performances of three alloys

\begin{tabular}{lllll}
\hline Alloy & MGC (wt\%) & RGC $(\mathrm{wt} \%)$ & DC $\left(\mathrm{mA} \mathrm{h} \mathrm{g}^{-1}\right)$ & $S_{100}(\%)$ \\
\hline $\mathrm{La}_{2} \mathrm{MgNi}_{9}$ & 1.594 & 1.15 & 350.8 & 70.3 \\
$\mathrm{La}_{1.5} \mathrm{Mg}_{0.5} \mathrm{Ni}_{7}$ & 1.619 & 1.275 & 365.5 & 75.4 \\
$\mathrm{La}_{4} \mathrm{MgNi}_{19}$ & 1.572 & 1.443 & 332.1 & 70.1 \\
\hline
\end{tabular}

$M G C$ the maximum gaseous absorption capacity, $R G C$ reversible gaseous capacity, $D C$ the maximum discharge capacity, $S_{100}$ electrochemical capacity retention after 100 cycles

\subsection{Overall Degradation Characteristics After Electrochemical Cycling}

Firstly, overall characters of the degradation behaviors of the three alloys after 100 electrochemical cyclings were generated. From morphology and EDS results, it is clear that pulverization and corrosion have occurred (only $\mathrm{La}_{2}$ $\mathrm{MgNi}_{9}$ alloy is presented in Fig. 4). XRD analysis shows that $\mathrm{La}(\mathrm{OH})_{3}, \mathrm{Mg}(\mathrm{OH})_{2}$ and $\mathrm{La}_{2} \mathrm{O}_{3}$ appear in the cycled
$\mathrm{La}_{1.5} \mathrm{Mg}_{0.5} \mathrm{Ni}_{7}$ and $\mathrm{La}_{4} \mathrm{MgNi}_{19}$ alloys, as displayed in Fig. 5. It is noteworthy that corrosion products of the cycled $\mathrm{La}_{2} \mathrm{MgNi}_{9}$ are less than the other two alloys where $\mathrm{Mg}(\mathrm{OH})_{2}$ is the main product. TEM observation of the cycled $\mathrm{La}_{2} \mathrm{MgNi}_{9}$ alloy shows three kinds of corrosion products including stick-, needle- and particle-like morphologies as illustrated in Fig. 6 (marked with 1, 2 and 3, respectively). Selected area electronic diffraction (SAED) and high-resolution TEM (HRTEM) identify the stick-,

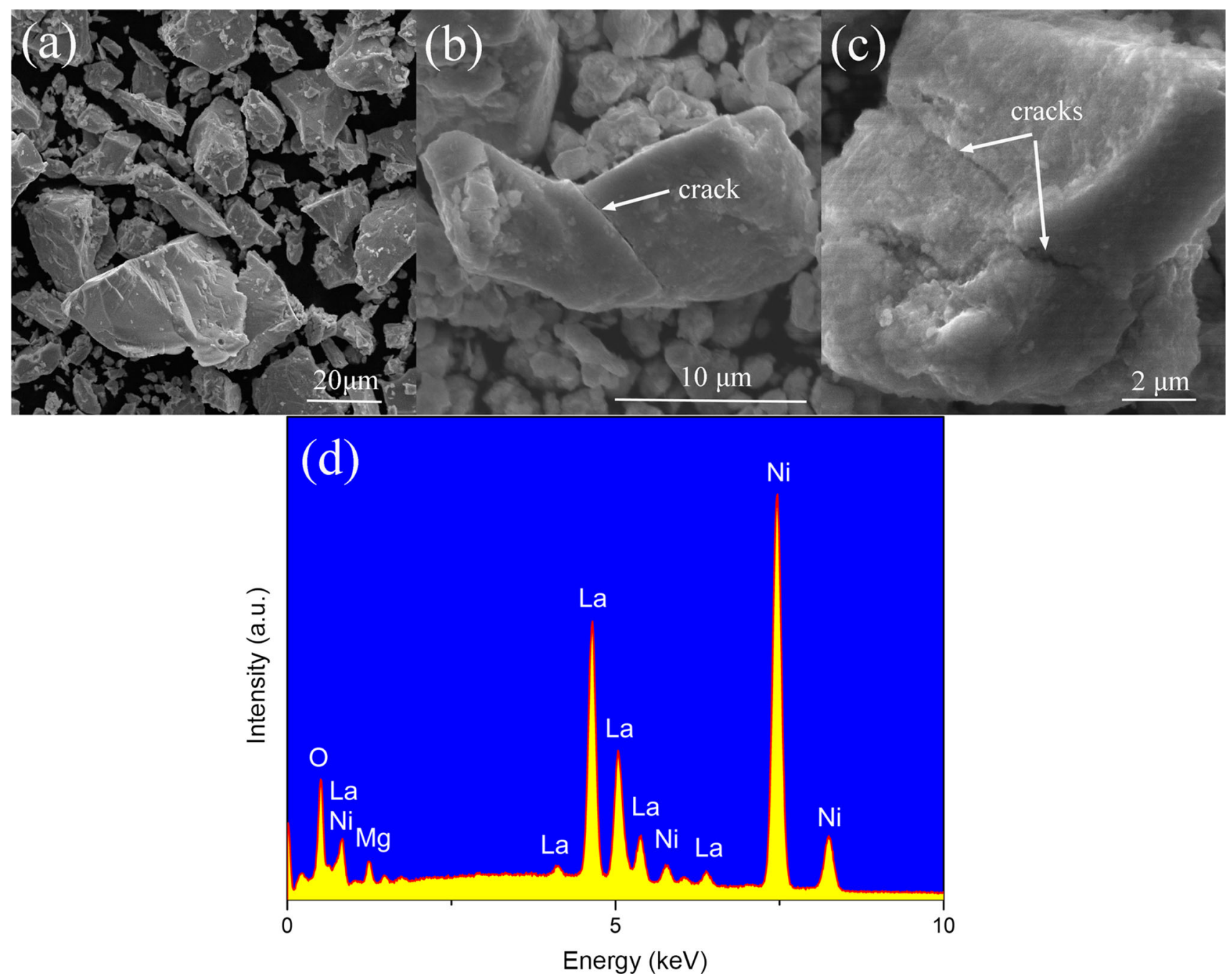

Fig. 4 Morphologies of original $\mathbf{a}$; electrochemical cycled particles at low $\mathbf{b}$; high $\mathbf{c}$ magnification, and EDS analysis of $\mathrm{La}_{2} \mathrm{MgNi}_{9} \mathrm{alloy}$ by cycling d 


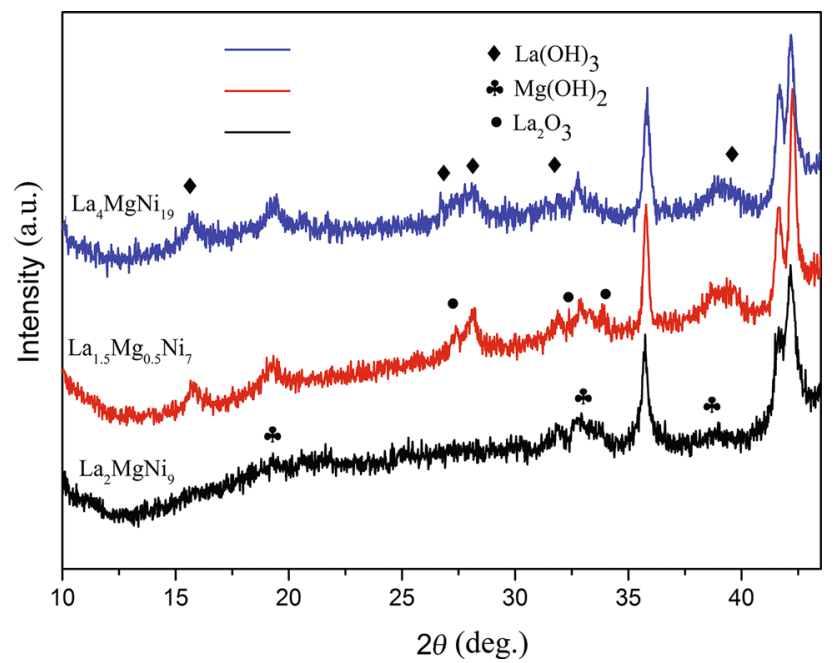

Fig. 5 XRD profiles of $\mathrm{La}_{2} \mathrm{MgNi}_{9}, \mathrm{La}_{1.5} \mathrm{Mg}_{0.5} \mathrm{Ni}_{7}$ and $\mathrm{La}_{4} \mathrm{MgNi}_{19}$ after electrochemical cycling

needle- and particle-like products to be $\mathrm{La}(\mathrm{OH})_{3}$ combined with $\mathrm{La}_{2} \mathrm{O}_{3}, \mathrm{Mg}(\mathrm{OH})_{2}$ and $\mathrm{MgO}$, details are provided in the supplementary information (Figs. S3-S5). The reason why $\mathrm{La}(\mathrm{OH})_{3}$ and $\mathrm{La}_{2} \mathrm{O}_{3}$ can hardly be detected in XRD in the cycled $\mathrm{La}_{2} \mathrm{MgNi}_{9}$ alloy may be due to their low content. The results are consistent with other studies on the corrosion products of a $\mathrm{La}_{1.5} \mathrm{Mg}_{0.5} \mathrm{Ni}_{7}$ alloy [25]. $\mathrm{Mg}(\mathrm{OH})_{2}$ and $\mathrm{MgO}$ are close to the alloy surface but very loose. It also agrees well with the previous works that corrosion products of $\mathrm{Mg}$ are gel type and cannot form a solid protective layer for further corrosion $[15,16]$.

Furthermore, oxygen contents (Table 4) of the electrochemical cycled alloys follow the order that $\mathrm{La}_{2}$ $\mathrm{MgNi}_{9}<\mathrm{La}_{1.5} \mathrm{Mg}_{0.5} \mathrm{Ni}_{7}<\mathrm{La}_{4} \mathrm{MgNi}_{19}$, which is coincident with that the cycled $\mathrm{La}_{2} \mathrm{MgNi}_{9}$ alloy presents much less corrosion products. This result raises question that corroded extent of the three alloys is inconsistent with the electrochemical performances that $\mathrm{La}_{2} \mathrm{MgNi}_{9}$ possesses poor cycling stability. It also disagrees with the consideration that high $\mathrm{Mg}$ content is harmful to the corrosion resistance in $\mathrm{La}-\mathrm{Mg}-\mathrm{Ni}$-based alloys [20, 26]. In order to comprehend this fact further, the intrinsic corrosion resistance of the three alloys was investigated next.

\subsection{Intrinsic Anti-corrosion Properties}

Because pulverization can increase the surface area and then accelerate corrosion, immersion corrosion test was adopted to avoid influence of pulverization on characterization of the intrinsic corrosion resistant. The alloy particles with the same diameter (around $40 \mu \mathrm{m}$ ) were immersed in $\mathrm{KOH}$ solution at $60{ }^{\circ} \mathrm{C}$ for $15 \mathrm{~d}$. Then the morphology, phase structure and oxygen content were measured for characterization of the intrinsic corrosion behaviors. SEM micrographs and EDS analysis of the alloy particles illustrate that severe corrosion occurred after immersion, and the typical results are shown in Fig. 7. (Only $\mathrm{La}_{2} \mathrm{MgNi}_{9}$ alloy particles are given here.) Compared to the electrochemical cycled alloys, the stick-like products which have been confirmed as composites of $\mathrm{La}(\mathrm{OH})_{3}$ and $\mathrm{La}_{2} \mathrm{O}_{3}$, are remarkable in the immersed samples which is due to aggravated corrosion at higher temperature.

XRD profiles identify that the corrosion products are mainly $\mathrm{La}(\mathrm{OH})_{3}$, but $\mathrm{La}_{2} \mathrm{O}_{3}$ cannot be detected in the immersed alloys, as shown in Fig. 8. Coincidently, It was found from SAED that the stick-shaped phase is singlephase $\mathrm{La}(\mathrm{OH})_{3}$, as shown in Fig. S6b. Besides, $\mathrm{Mg}(\mathrm{OH})_{2}$ and $\mathrm{MgO}$ are also found existing in the immersed samples, and their morphologies are the same with that in the electrochemical cycled alloys (Fig. S6). However, $\mathrm{Mg}(\mathrm{OH})_{2}$ can only be detected in $\mathrm{La}_{2} \mathrm{MgNi}_{9}$ from identification of $\mathrm{XRD}$, indicating that corrosion of $\mathrm{Mg}$ is violent in $\mathrm{La}_{2} \mathrm{MgNi}_{9}$. Oxygen contents of the immersed alloys as listed in Table 4 indicate that severity of corrosion of the three alloys are $\mathrm{La}_{2} \mathrm{MgNi}_{9}>\mathrm{La}_{1.5} \mathrm{Mg}_{0.5} \mathrm{Ni}_{7}>\mathrm{La}_{4} \mathrm{MgNi}_{19}$.
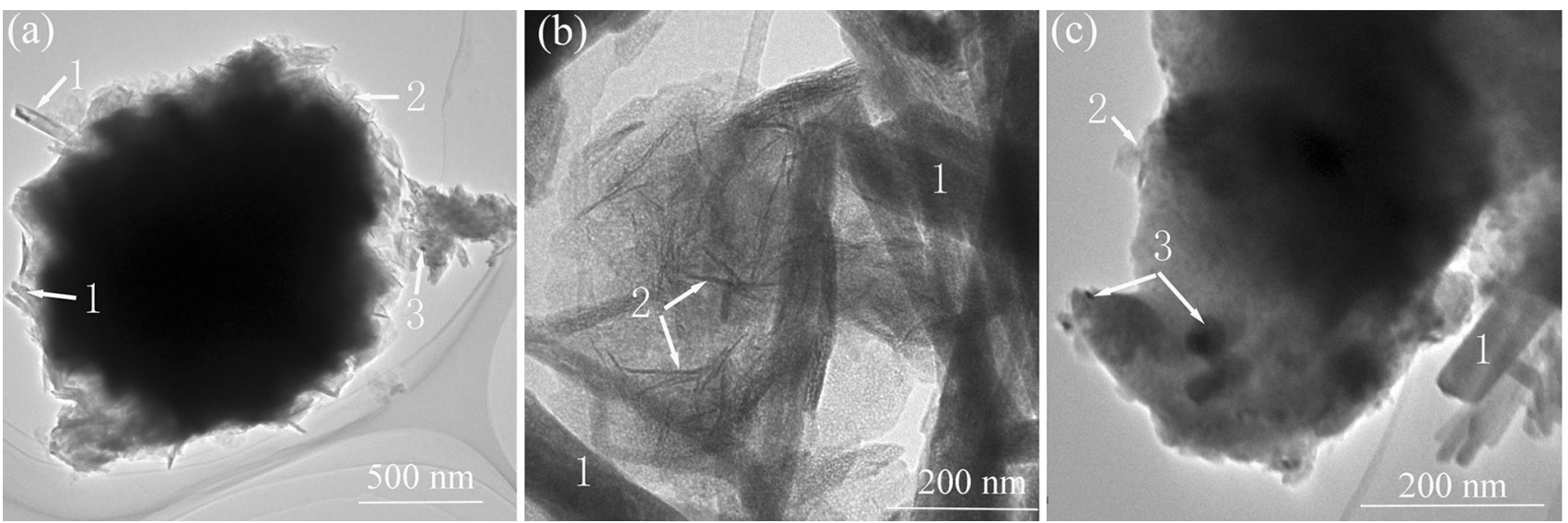

Fig. 6 TEM images of alloy particles at $\mathbf{a}$ low; $\mathbf{b}$, $\mathbf{c}$ high magnification of $\mathrm{La}_{2} \mathrm{MgNi}_{9}$ alloy after electrochemical cycling 
Table 4 Oxygen contents and size retention of alloys

\begin{tabular}{llll}
\hline Alloy & Oxygen content after electrochemical cycling (wt\%) & $\begin{array}{l}\text { Oxygen content }(w t \%) \\
\text { after immersion }\end{array}$ & Size retention after gaseous cycling (\%) \\
\hline $\mathrm{La}_{2} \mathrm{MgNi}_{9}$ & 2.68 & 4.66 & 84.6 \\
$\mathrm{La}_{1.5} \mathrm{Mg}_{0.5} \mathrm{Ni}_{7}$ & 3.21 & 4.38 & 68.5 \\
$\mathrm{La}_{4} \mathrm{MgNi}_{19}$ & 3.62 & 4.14 & 66.5 \\
\hline
\end{tabular}
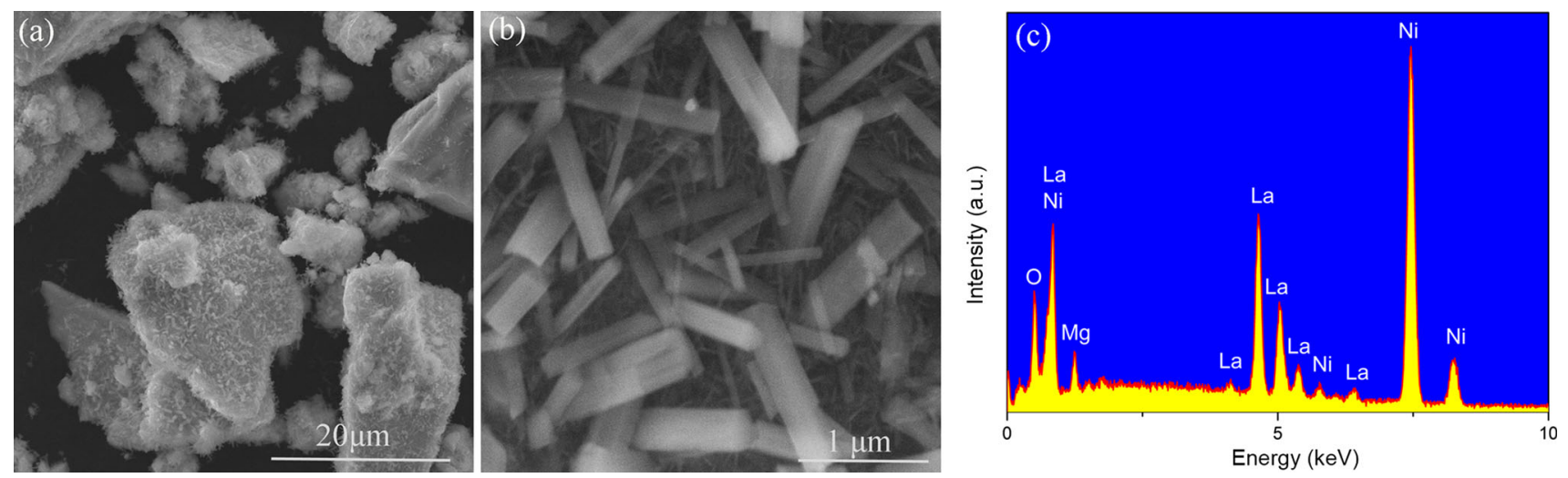

Fig. 7 Morphologies at low $\mathbf{a}$; high $\mathbf{b}$; magnification and EDS spectra $\mathbf{c}$ of $\mathrm{La}_{2} \mathrm{MgNi}_{9}$ particles after immersion

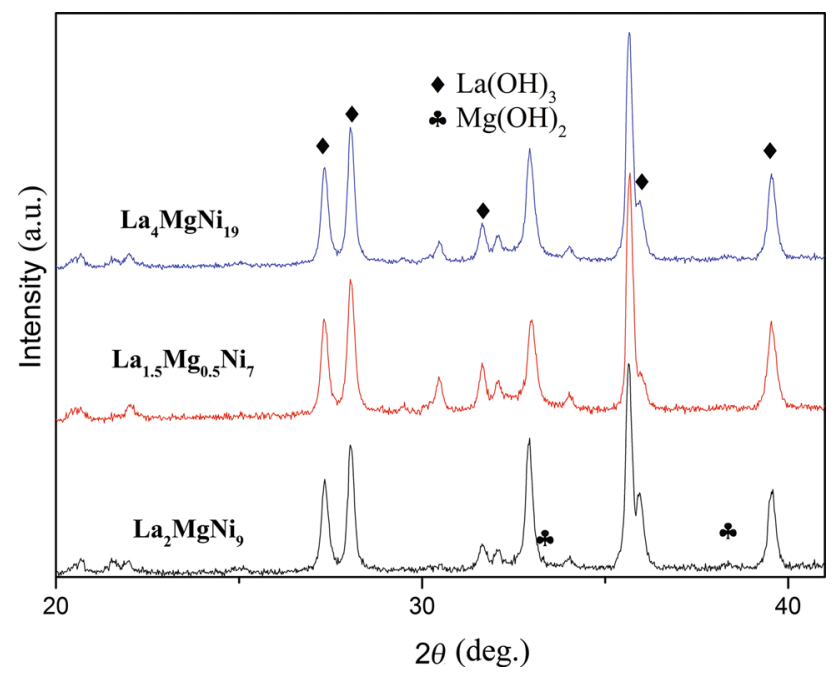

Fig. 8 XRD profiles of $\mathrm{La}_{2} \mathrm{MgNi}_{9}, \mathrm{La}_{1.5} \mathrm{Mg}_{0.5} \mathrm{Ni}_{7}$ and $\mathrm{La}_{4} \mathrm{MgNi}_{19}$ alloys after immersion

This trend is the same with that in Ref. [21] where oxygen contents of single-phase $\mathrm{La}_{2} \mathrm{MgNi}_{9}, \mathrm{La}_{3} \mathrm{MgNi}_{14}$ and $\mathrm{La}_{4}$ $\mathrm{MgNi}_{19}$ alloys gradually increase after electrochemical cycling.

To provide detailed information of the relationship between the corrosion behaviors and phase constitution, immersion test was also applied to massive samples. (The condition is the same with that of the powder samples.) Figure 9 shows SEM-BSE micrographs of the immersed samples. (Only $\mathrm{La}_{1.5} \mathrm{Mg}_{0.5} \mathrm{Ni}_{7}$ alloy is present here.) Obviously, the corroded extent is inhomogeneous which is considered to be caused by differences in the anti-corrosion capabilities of the various phases. EDS analysis on two regions with diverse corrosion grades (as marked with 1 and 2 in Fig. 9a) shows no $\mathrm{Mg}$ but less $\mathrm{O}$ existing in region 1. While, high content of $\mathrm{Mg}$ and $\mathrm{O}$ can be detected in region 2 with more severe corroded extent. Likewise, EDS mapping indicates that the region possessing more $\mathrm{Mg}$ presents richer O, as shown in Fig. 10. Similar result is more evident in the as-cast alloys, which is attributed to the inhomogeneous chemical composition of the as-cast alloy, details can be seen in the supplementary information (Figs. S7 and S8).

The aforementioned results demonstrate that the $\mathrm{Mg}$ rich phases are easy to be corroded in the alkaline solution. It has been well demonstrated that $\mathrm{Mg}$ solubility in $\mathrm{La}-\mathrm{Mg}$ $\mathrm{Ni}$ alloys follows the order that $(\mathrm{La}, \mathrm{Mg}) \mathrm{Ni}_{2}>(-$ $\mathrm{La}, \mathrm{Mg}) \mathrm{Ni}_{3}>(\mathrm{La}, \mathrm{Mg})_{2} \mathrm{Ni}_{7}>(\mathrm{La}, \mathrm{Mg})_{5} \mathrm{Ni}_{19}>\mathrm{LaNi}_{5}$ [27]. Thus, the intrinsic corrosion resistances of various phases in the La-Mg-Ni system are considered to be according with the inverse trend. This result is in agreement with several works where $A B_{2}$ - and $A B_{3}$-type $\mathrm{La}-\mathrm{Mg}-\mathrm{Ni}$ alloys have suffered serious corrosion after electrochemical experiments $[8,20,21]$. The tendency is also exactly identical with that the corrosion resistance is inversely proportional to the abundance of the $\mathrm{Mg}$-rich phases. $\mathrm{La}_{2} \mathrm{MgNi}_{9}$ presents worse anti-corrosion capability because 

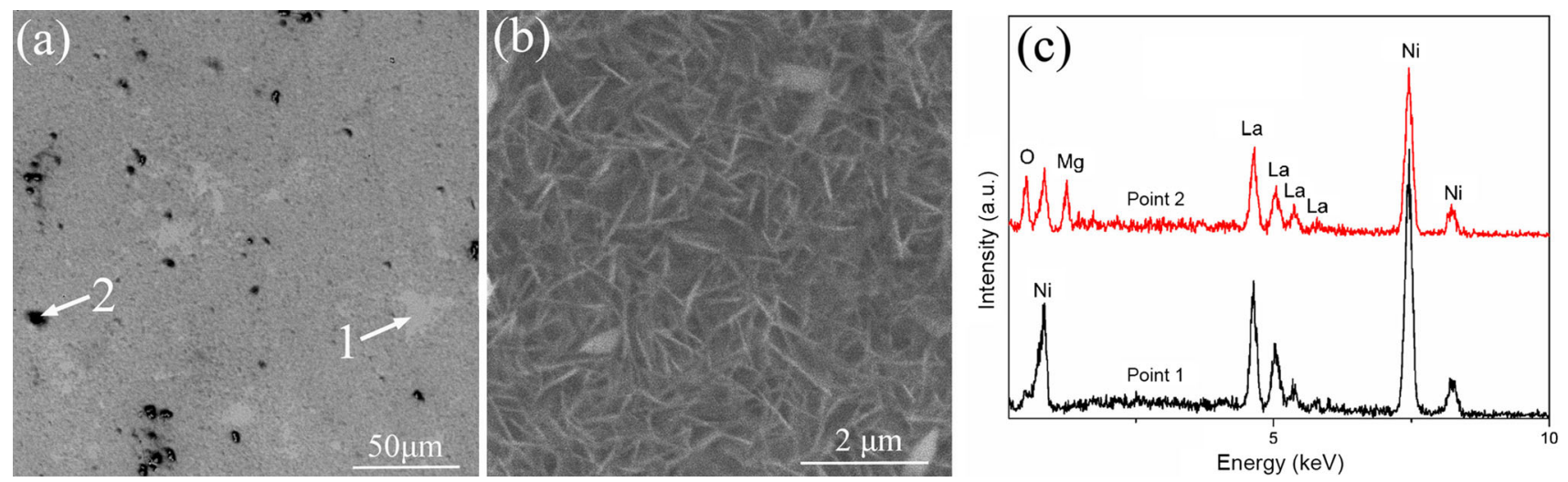

Fig. 9 SEM images at low $\mathbf{a}$; high $\mathbf{b}$; magnification, EDS spectra of different points $\mathbf{c}$ in annealed $\operatorname{La}_{1.5} \mathrm{Mg}_{0.5} \mathrm{Ni}_{7}$ alloy after immersion

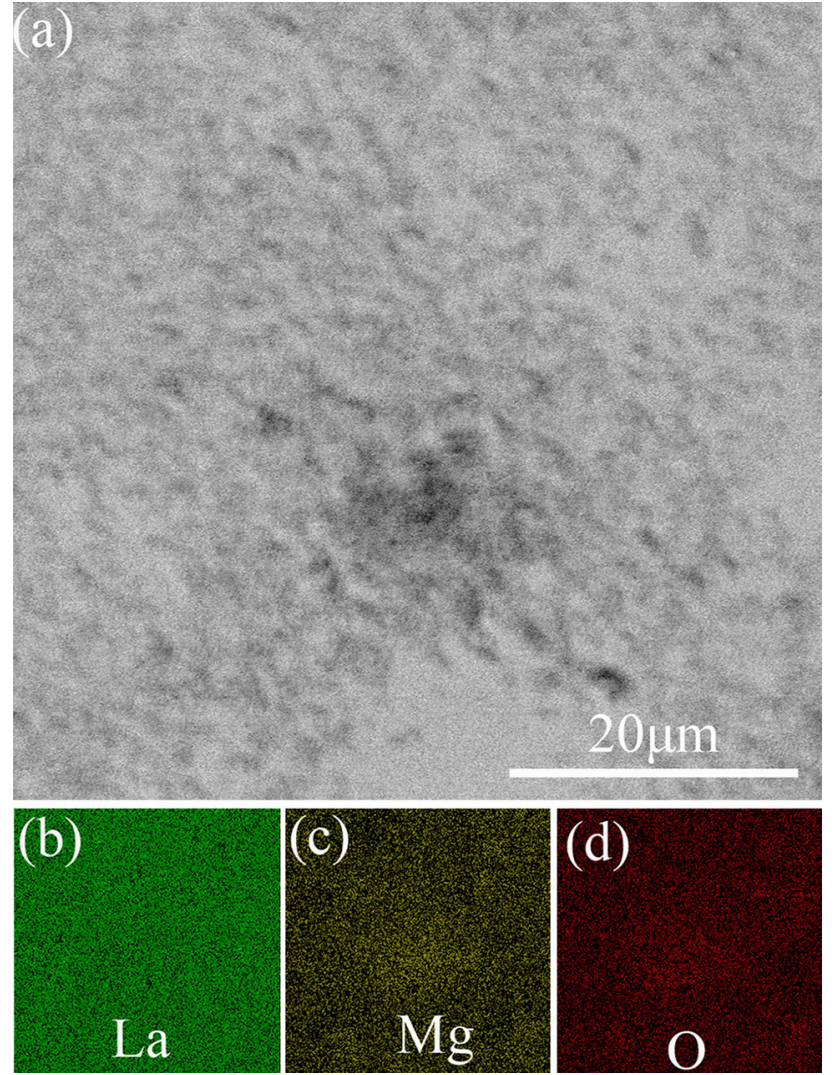

Fig. 10 EDS mapping $\mathbf{a}$; elements $\mathrm{La} \mathbf{b} ; \mathrm{Mg} \mathbf{c} ; \mathrm{O} \mathbf{d}$ distribution of annealed $\mathrm{La}_{1.5} \mathrm{Mg}_{0.5} \mathrm{Ni}_{7}$ alloy after immersion

the contents of the $\mathrm{Mg}$-rich $(\mathrm{La}, \mathrm{Mg}) \mathrm{Ni}_{2}$ and $(\mathrm{La}, \mathrm{Mg}) \mathrm{Ni}_{3}$ are higher than the other two alloys. However, it is also puzzled that the trend of the intrinsic corrosion resistance is opposite to the overall corrosion extent of the three alloys after electrochemical cyclings. Concern to the fact that corrosion extent of the electrode alloys is also closely related to severity of pulverization during the electrochemical charge/discharge process, the pulverization properties of the alloys are carefully characterized then.

\subsection{Intrinsic Anti-pulverization Properties}

In order to avoid the influence of the additives in the electrochemical test on characterization of the intrinsic pulverization behavior, the alloys are gaseous hydrogenated and dehydrogenated for 30 cycles. Morphology observation indicates that remarkable pulverization has occurred and the decrease in the particle size and emergence of cracks can be seen clearly in the cycled alloys, as shown in Fig. 11. (Only $\mathrm{La}_{2} \mathrm{MgNi}_{9}$ alloy is present here.)

Then the particle sizes before and after cycling $\left(S_{\mathrm{b}}\right.$ and $S_{\mathrm{a}}$, respectively) are measured, and the size retention is calculated by $S_{\mathrm{b}} / S_{\mathrm{a}}$ as displayed in Table 4 . It shows that severity of pulverization for the three alloys are $\mathrm{La}_{2}$ $\mathrm{MgNi}_{9}<\mathrm{La}_{1.5} \mathrm{Mg}_{0.5} \mathrm{Ni}_{7}<\mathrm{La}_{4} \mathrm{MgNi}_{19}$, which is just contrary to the tendency of the corrosion extent after the immersion experiment. Combined with the results of the intrinsic anti-corrosion and pulverization characterization, we can conclude that the weaker corrosion extent of $\mathrm{La}_{2}$ $\mathrm{MgNi}_{9}$ in the electrochemical test is attributed to its better intrinsic anti-pulverization capability though the intrinsic anti-corrosion of $\mathrm{La}_{2} \mathrm{MgNi}_{9}$ is worse.

It has been well accepted that pulverization is induced by the cell volume expansion upon hydrogen absorption $[11,12]$. Thus, large volume change will lead to severe pulverization. Unfortunately, exact measurement of the volume expansion in the present work is difficult due to the multi-phase microstructure. Instead, we summarize the volume changes according to other experimental works [11, 28-31] where microstructures of these alloys are all single phases to ensure the accuracy as far as possible. Based on the data as listed in Table 5, there is no regular trend for the volume changes among the various structures in La-Mg-Ni system. And, no unique relationship between the reported volume expansion data and the pulverization performances in the present work can be found.

Besides, pulverization is also believed to depend on the mechanical properties of the alloys [11, 12]. Alloys with 

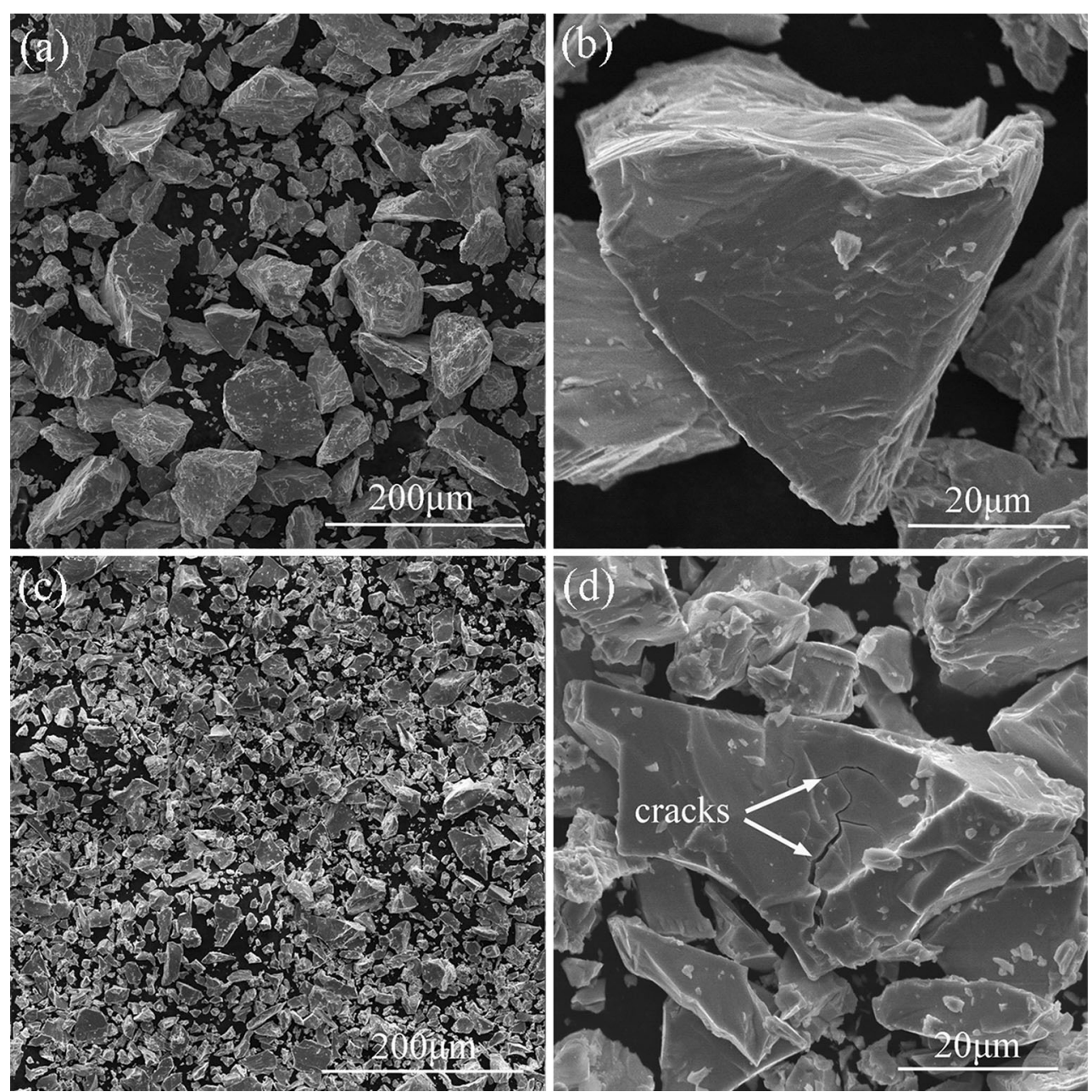

Fig. 11 Morphologies of the $\mathrm{La}_{2} \mathrm{MgNi}_{9}$ particles before $\mathbf{a}, \mathbf{b}$; after $\mathbf{c}, \mathbf{d}$; gaseous cycling at low $\mathbf{a}, \mathbf{c}$; and high $\mathbf{b}, \mathbf{d}$ magnification

Table 5 Volume expansion of various La-Mg-Ni phases by hydrogenation in the reported works

\begin{tabular}{llllllll}
\hline Alloy & $\mathrm{La}_{2.3} \mathrm{Mg}_{0.7} \mathrm{Ni}_{9}$ & $\mathrm{La}_{2} \mathrm{MgNi}_{9}$ & $\mathrm{LaMg}_{2} \mathrm{Ni}_{9}$ & $\mathrm{La}_{1.5} \mathrm{Mg}_{0.5} \mathrm{Ni}_{7}$ & $\mathrm{La}_{1.63} \mathrm{Mg}_{0.37} \mathrm{Ni}_{7}$ & $\mathrm{La}_{4} \mathrm{MgNi}_{19}$ & $\mathrm{LaNi}_{5}$ \\
\hline Type & $\mathrm{AB}_{3}$ & $\mathrm{AB}_{3}$ & $\mathrm{AB}_{3}$ & $\mathrm{~A}_{2} \mathrm{~B}_{7}$ & $\mathrm{~A}_{2} \mathrm{~B}_{7}$ & $\mathrm{~A}_{5} \mathrm{~B}_{19}$ & $\mathrm{AB}_{5}$ \\
$\Delta V / V$ & 27.1 & 26.7 & 23 & 25.2 & 25.6 & 25.3 & 24 \\
References & {$[28]$} & {$[28]$} & {$[29]$} & {$[30]$} & {$[30]$} & {$[31]$} & {$[11]$} \\
\hline
\end{tabular}

the more ductile character are more resistant to pulverization than the brittle materials. Usually, hydrogen storage alloys are hard and brittle; thus, direct measurement of the ductility is difficult. Alternatively, Vickers hardness has been used to evaluate the preference of pulverization for the hydrogen storage alloys. And, previous works have found an almost inverse relationship between Vickers hardness and the pulverization rate [11, 12, 32], suggesting the availability of Vickers hardness measurement for characterization of the anti-pulverization ability.

Figure 12 shows the microstructures after indentations of various phases in $\mathrm{La}_{2} \mathrm{MgNi}_{9}$ and $\mathrm{La}_{1.5} \mathrm{Mg}_{0.5} \mathrm{Ni}_{7}$ alloys. Evolution of Vickers hardness can be seen in Fig. 13. It presents a linear relation between the Vickers hardness and $B$-side stoichiometry of the structures, which also agrees well with the pulverization behaviors of the alloys. Obviously, the mechanical property is an important factor affecting the anti-pulverization ability of the La-Mg-Ni phases. Under low loading in the hardness test, microcracks can hardly be observed in all three phases. As the test force increases, micro-cracks can be seen in all these phases, but there is no obvious difference between them. Differently, $\mathrm{LaNi}_{5}$ is the hard phase, but hardness of $(\mathrm{La}, \mathrm{Mg}) \mathrm{Ni}_{2}$ is far more lower than the other phases.

To comprehend more understanding on the crack formation of various phases, a massive sample with a polished 

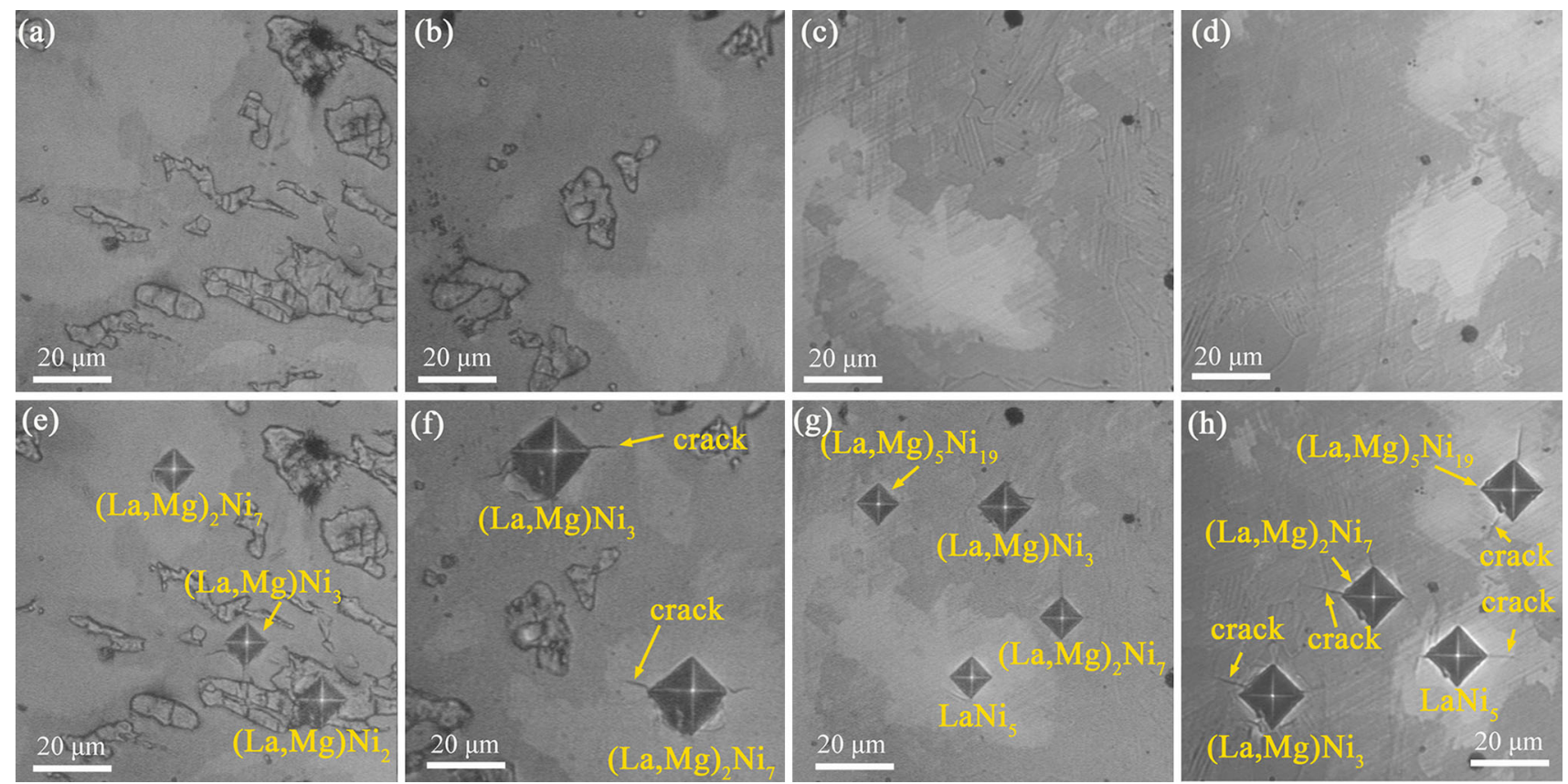

Fig. 12 Original optical images of $\mathrm{La}_{2} \mathrm{MgNi}_{9} \mathbf{a}, \mathbf{b} ; \mathrm{La}_{1.5} \mathrm{Mg}_{0.5} \mathrm{Ni}_{7} \mathbf{c}, \mathbf{d} ;$ alloys, and indentation morphologies of $\mathrm{La}_{2} \mathrm{MgNi}_{9} \mathbf{e}, \mathbf{f} ; \mathrm{La}_{1.5} \mathrm{Mg}_{0.5} \mathrm{Ni}_{7} \mathbf{g}$, $\mathbf{h}$; alloys $\mathbf{e}, \mathbf{g} ; \mathbf{f}, \mathbf{h}$ were tested under 10 and $25 \mathbf{g}, \mathbf{f}$, respectively)

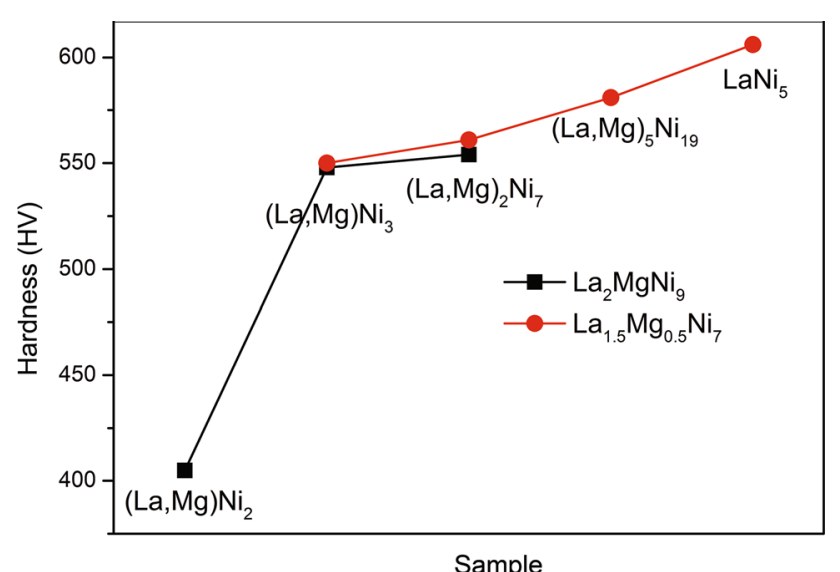

Fig. 13 Micro-hardness of various phases

surface was partially charged by electrochemical method, and the morphology and distribution of cracks were observed. To highlight characters of the hard and soft phases, the as-cast $\mathrm{La}_{2} \mathrm{MgNi}_{9}$ alloy was selected for the high content of $\mathrm{LaNi}_{5}$ and $(\mathrm{La}, \mathrm{Mg}) \mathrm{Ni}_{2}$. Microstructure characteristics of the as-cast $\mathrm{La}_{2} \mathrm{MgNi}_{9}$ alloy are given in the supplementary (Figs. S9 and S10). As shown in Fig. 14, quite a number of cracks can be observed in the sample which is only charged for $10 \mathrm{~min}$. Most of the cracks exist in $\mathrm{LaNi}_{5}$ with the darkest contrast in the BSE image. One reason is that $\mathrm{LaNi}_{5}$ is the catalytic phase that is primarily charged in the La-Mg-Ni system [33, 34]. More importantly, it is also ascribed to the brittle character of $\mathrm{LaNi}_{5}$ which agrees well with the above result that the hard phase is easy to form crack.

It is noteworthy that cracks are often stopped in front of ( $\mathrm{La}, \mathrm{Mg}$ ) $\mathrm{Ni}_{2}$. Obviously, the soft phase is more resistant to form crack and able to prevent the crack spreading. Similar result has been reported in other studies where ductile secondary phases are believed to be beneficial to the cycling stability [35]. However, our results are different from Ref. [21] that pulverization of single-phase $\mathrm{La}_{2-}$ $\mathrm{MgNi}_{9}, \mathrm{La}_{3} \mathrm{MgNi}_{14}$ and $\mathrm{La}_{4} \mathrm{MgNi}_{19}$ alloys present an increasing trend which is considered to be caused by the discrete expansion/contraction of $\left[A B_{5}\right]$ and $\left[A B_{2}\right]$ subunits. This may be attributed to the multi-phase microstructure in the present work. Based on our results, hardness differences of the $A B_{3^{-}}, A_{2} B_{7^{-}}$and $A_{5} B_{19^{-}}$type phase are small. While, $\mathrm{LaNi}_{5}$ presents obvious brittle nature and severe pulverization of $\mathrm{La}_{4} \mathrm{MgNi}_{19}$ is attibuted to the high content of $\mathrm{LaNi}_{5}$. As to $\mathrm{La}_{2} \mathrm{MgNi}_{9}$, little $\mathrm{LaNi}_{5}$ but existence of the soft $(\mathrm{La}, \mathrm{Mg}) \mathrm{Ni}_{2}$ make it more resistant to crack emergence. These findings also enlighten a way to improve the antipulverization ability by introducing appropriate content and distribution of soft secondary phases.

\section{Conclusion}

In the present study, corrosion and pulverization behaviors of three typical La-Mg-Ni alloys, $\mathrm{La}_{2} \mathrm{MgNi}_{9}, \mathrm{La}_{1.5} \mathrm{Mg}_{0.5}$ $\mathrm{Ni}_{7}$ and $\mathrm{La}_{4} \mathrm{MgNi}_{19}$ have been systematically investigated. 

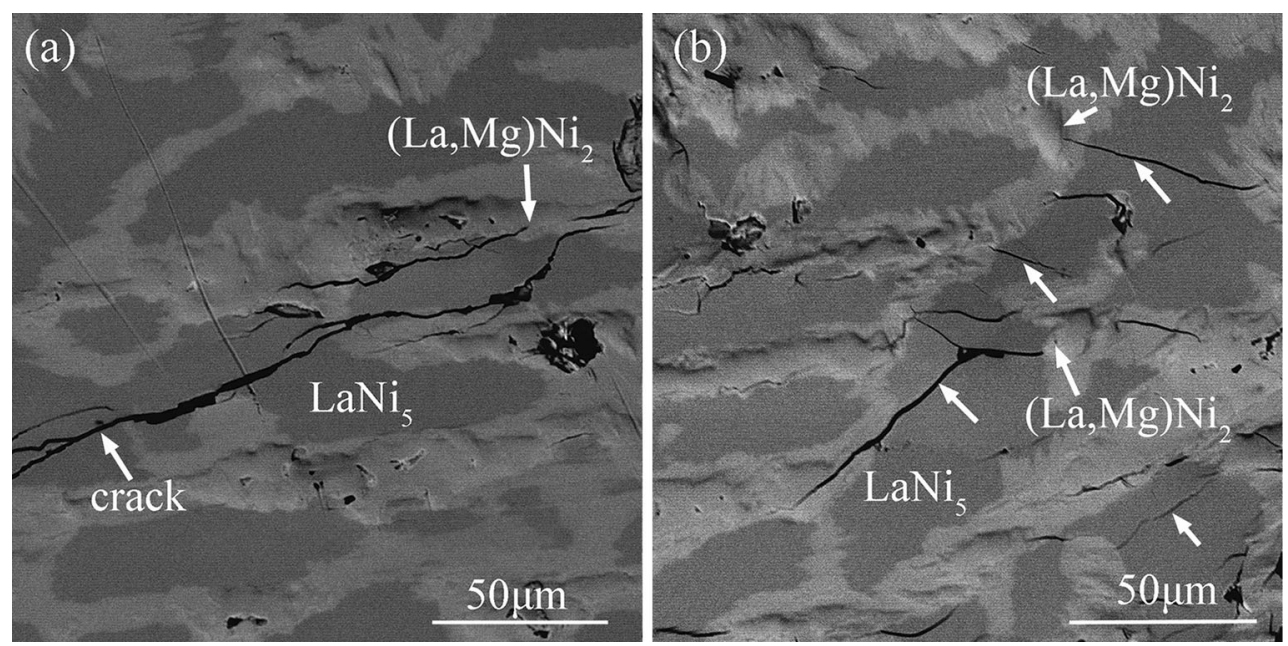

Fig. 14 Morphologies of as-cast $\mathrm{La}_{2} \mathrm{MgNi}_{9}$ alloy in different regions $\mathbf{a}, \mathbf{b}$ after being partially charged

All the alloys present multi-phase microstructure with (La, $\mathrm{Mg}) \mathrm{Ni}_{3},(\mathrm{La}, \mathrm{Mg})_{2} \mathrm{Ni}_{7}$ and $(\mathrm{La}, \mathrm{Mg})_{5} \mathrm{Ni}_{19}$ as the main phase, respectively. $\mathrm{La}_{1.5} \mathrm{Mg}_{0.5} \mathrm{Ni}_{7}$ possesses better electrochemical properties among the three alloys. It is found that pulverization and corrosion with the main product $\mathrm{La}(\mathrm{OH})_{3}$, combined with $\mathrm{La}_{2} \mathrm{O}_{3}, \mathrm{Mg}(\mathrm{OH})_{2}$ and $\mathrm{MgO}$, have occurred after the electrochemical cycling. The overall corrosion extent of the electrochemical cycled alloys follow the order $\mathrm{La}_{2} \mathrm{MgNi}_{9}<\mathrm{La}_{1.5} \mathrm{Mg}_{0.5} \mathrm{Ni}_{7}<\mathrm{La}_{4} \mathrm{MgNi}_{19}$. Immersion test demonstrates that the $\mathrm{Mg}$-rich phases are easy to be corroded in the alkaline solution. The intrinsic corrosion resistance are found to be $\mathrm{La}_{2} \mathrm{MgNi}_{9}<\mathrm{La}_{1.5}$ $\mathrm{Mg}_{0.5} \mathrm{Ni}_{7}<\mathrm{La}_{4} \mathrm{MgNi}_{19}$, which is inversely proportional to the content of the Mg-rich phases. However, the intrinsic anti-pulverization ability just presents an inverse trend which is $\mathrm{La}_{2} \mathrm{MgNi}_{9}>\mathrm{La}_{1.5} \mathrm{Mg}_{0.5} \mathrm{Ni}_{7}>\mathrm{La}_{4} \mathrm{MgNi}_{19}$. It is found that the mechanical property is an important factor affecting the anti-pulverization ability. Vickers hardness elevates with the increase in the $B$-side stoichiometry of the various phases, which agrees well with the pulverization behaviors of the alloys. Furthermore, $\mathrm{LaNi}_{5}$ with the highest hardness is found to be easy for crack formation, but the soft $(\mathrm{La}, \mathrm{Mg}) \mathrm{Ni}_{2}$ is more resistant to form crack and able to prevent the crack spreading. The weaker corrosion extent of $\mathrm{La}_{2} \mathrm{MgNi}_{9}$ in the electrochemical test is attributed to its better intrinsic anti-pulverization capability though the intrinsic anti-corrosion of $\mathrm{La}_{2} \mathrm{MgNi}_{9}$ is worse.

Acknowledgements This work was supported financially by the National Natural Science Foundation of China (No. 51761032) and the Natural Science Foundation Application of Inner Mongolia (No. 2014MS0526).

\section{References}

[1] J. Chen, N. Kuriyama, H.T. Takeshita, H. Tanaka, T. Sakai, M. Haruta, Electrochem. Solid-State Lett. 3, 249 (2000)

[2] Y.H. Zhang, Z.M. Yuan, T. Yang, Z.H. Hou, D.L. Zhao, Acta Metall. Sin. (Engl. Lett.) 28, 826 (2015)

[3] S. Yasuoka, Y. Magari, T. Murata, T. Tadayoshi, J. Ishida, H. Nakamura, T. Nohma, K. Masaru, J. Power Sour. 156, 662 (2006)

[4] Y.F. Liu, Y.H. Cao, L. Huang, M.X. Gao, H.G. Pan, J. Alloys Compd. 509, 675 (2011)

[5] J.J. Liu, S.M. Han, Y. Li, L. Zhang, Y.M. Zhao, S.Q. Yang, B.Z. Liu, Int. J. Hydrogen Energy 41, 20261 (2016)

[6] J. Guo, D. Huang, G.X. Li, S.Y. Ma, W.L. Wei, Mater. Sci. Eng. B 131, 169 (2006)

[7] B. Liao, Y.Q. Lei, G.L. Lu, L.X. Chen, H.G. Pan, Q.D. Wang, J. Alloys Compd. 356-357, 746 (2003)

[8] T. Yang, T.T. Zhai, Z.M. Yuan, W.G. Bu, S. Xu, Y.H. Zhang, J. Alloys Compd. 617, 29 (2014)

[9] X. Cai, F.S. Wei, F.N. Wei, H.H. Lu, Acta Metall. Sin. (Engl. Lett.) 29, 614 (2017)

[10] Y. Zhang, F.S. Wei, J.N. Xiao, X. Cai, Acta Metall. Sin. (Engl. Lett.) (2017). https://doi.org/10.1007/s40195-017-0577-4

[11] T. Sakai, K. Oguro, H. Miyamura, N. Kuriyama, A. Kato, H. Ishikawa, J. Less-Common Met. 161, 193 (1990)

[12] D. Chartouni, F. Meli, A. Züttel, K. Gross, L. Schlapbach, J. Alloys Compd. 241, 160 (1996)

[13] B. Liao, Y.Q. Lei, L.X. Chen, G.L. Lu, H.G. Pan, Q.D. Wang, J. Power Sour. 129, 358 (2004)

[14] Y.F. Liu, H.G. Pan, Y.J. Yue, X.F. Wu, N. Chen, Y.Q. Lei, J. Alloys Compd. 395, 291 (2005)

[15] X.Z. Sun, H.G. Pan, M.X. Gao, R. Li, Y. Lin, S. Ma, Trans. Nonferrous Met. Soc. China 16, 8 (2006)

[16] P. Zhang, Y.N. Liu, J.W. Zhu, X.D. Wei, G. Yu, Int. J. Hydrogen Energy 32, 2488 (2007)

[17] Y.H. Zhang, D.L. Zhao, B.W. Li, H.P. Ren, X.P. Dong, X.L. Wang, Trans. Nonferrous Met. Soc. China 17, 816 (2007)

[18] Y.M. Li, H.W. Zhang, Y.H. Zhang, H.P. Ren, Rare Met. 36, 101 (2017)

[19] Y.M. Li, H.P. Ren, Y.H. Zhang, Z.C. Liu, H.W. Zhang, Int. J. Hydrogen Energy 40, 7093 (2015)

[20] F. Li, K. Young, T. Ouchi, M.A. Fetcenko, J. Alloys Compd. 471, 371 (2009) 
[21] J.J. Liu, Y. Li, D. Han, S.Q. Yang, X.C. Chen, L. Zhang, S.M. Han, J. Power Sour. 300, 77 (2015)

[22] J.J. Liu, S.M. Han, Y. Li, S.Q. Yang, W.Z. Shen, L. Zhang, Y. Zhou, J. Alloys Compd. 552, 119 (2013)

[23] J. Kleperis, G. Wójcil, A. Czerwinski, J. Skowronski, M. Kopczyk, M. Beltowska-Brzezinska, J. Solid State Electrochem. 5, 229 (2001)

[24] W.K. Hu, R.V. Denys, C.C. Nwakwuo, T. Holm, J.P. Maehlen, J.K. Solberg, V.A. Yartys, Electrochim. Acta 96, 27 (2013)

[25] J. Monnier, H. Chen, S. Joiret, J. Bourgon, M. Latroche, J. Power Sour. 266, 162 (2014)

[26] F.L. Zhang, Y.C. Luo, J.P. Chen, R.X. Yan, J.H. Chen, J. Alloys Compd. 430, 302 (2007)

[27] J.C. Crivello, J. Zhang, M. Latroche, J. Phys. Chem. C 115, 25470 (2011)
[28] R.V. Denys, V.A. Yartys, J. Alloys Compd. 509, S540 (2011)

[29] R.V. Denys, A.B. Riabov, V.A. Yartys, M. Sato, R.G. Delaplane, J. Solid State Chem. 181, 812 (2008)

[30] M.N. Guzik, B.C. Hauback, K. Yvon, J. Solid State Chem. 186, 9 (2012)

[31] J. Nakamura, K. Iwase, H. Hayakawa, Y. Nakamura, E. Akiba, J. Phys. Chem. C 113, 5853 (2009)

[32] M.X. Gao, S.C. Zhang, H. Miao, Y.F. Liu, H.G. Pan, J. Alloys Compd. 489, 552 (2010)

[33] Y.F. Liu, H.G. Pan, M.X. Gao, Y.Q. Lei, Q.D. Wang, J. Alloys Compd. 403, 296 (2005)

[34] Y.M. Li, Y.H. Zhang, H.P. Ren, Z.C. Liu, H. Sun, Int. J. Hydrogen Energy 41, 18571 (2016)

[35] R. Tang, Y.N. Liu, C.C. Zhu, J.W. Zhu, G. Yu, Intermetallics 14, 361 (2006) 